\section{HEPATITIS C VIRUS TRANSMISSION DURING ORGAN TRANSPLANTATION}

Pereira BJG, Milford EL, Kirkman RL, Quan S, Sayre $K R$, Johnson PJ, Wilber JC, et al. Prevalence of hepatitis $\mathrm{C}$ virus RNA in organ donors positive for hepatitis $\mathrm{C}$ antibody and in recipients of their organs. $\mathrm{N}$ Engl J Med 1992;327:910-915.

\section{ABSTRACT}

Background. There is a high prevalence of liver disease among the recipients of organs from donors with antibodies to hepatitis $C$ virus (HCV). We undertook a study to determine the frequency of persistent HCV infection, as indicated by the presence of HCV RNA, among both cadaveric organ donors positive for antibodies to HCV (anti-HCV) and the recipients of organs from these donors.

Methods. Serum samples from donors and recipients were tested for HCV RNA with the reverse transcriptase polymerase chain reaction, with use of primers from the 5 ' untranslated region of the $\mathrm{HCV}$ genome, and for anti-HCV with the first-generation enzyme-linked immunosorbent assay (ELISA) and two second-generation tests.

Results. HCV RNA was detected in 9 of 11 organ donors (82 percent) with a positive first-generation ELISA for anti-HCV. Among the organ recipients, the prevalence of HCV RNA increased after transplantation: 7 of 26 patients (27 percent) had positive samples before transplantation, as compared with 23 of 24 patients (96 percent) after transplantation $(P<0.001)$. Among 13 recipients who were HCV RNAnegative before receiving organs from the nine $\mathrm{HCV}$ RNA-positive donors, HCV infection was detected in all 13 after transplantation, and anti-HCV developed in 8 (62 percent). On the basis of a positive test for $\mathrm{HCV}$ RNA, the maximal sensitivity of the three anti-HCV tests was 57 percent (positive in 4 of 7 patients with end-stage organ failure) before transplantation and $\mathbf{7 0}$ percent (positive in 16 of 23 patients) after transplantation.

Conclusions. Nearly all the recipients of organs from anti-HCV-positive donors become infected with HCV. The current tests for anti-HCV antibodies underestimate the incidence of transmission and the prevalence of $\mathrm{HCV}$ infection among immunosuppressed organ recipients.

Roth D, Fernandez JA, Babischkin S, De Mattos A, Buck BE, Quan S, Olson L, et al. Detection of hepatitis C virus infection among cadaver organ donors: evidence for low transmission of disease. Ann Intern Med 1992;117:1705-1709.

$31 / 8 / 43758$

$0270-9139 / 93 / \$ 1.00+\$ 0.10$

\section{ABSTRACT}

Objective: To determine the prevalence of antibodies to hepatitis $\mathrm{C}$ virus (anti-HCV) and HCV RNA among cadaver organ donors and to correlate these results with donor liver histologic abnormalities and evidence for transmission of disease through organ transplantation.

Design: Retrospective testing of stored serum samples from cadaver organ donors for anti-HCV and HCV RNA.

Setting: Transplantation service of the University of Miami/Jackson Memorial Medical Center and other cooperative medical centers furnishing follow-up data.

Subjects: Of 1096 cadaver organ donors harvested between 1 January 1979 and 28 February 1991, 484 had stored serum samples available for analysis. Recipients of organs from recombinant immunoblot assay (RIBA)-positive donors for whom adequate follow-up was available were also included in the analysis.

Measurements: Samples were tested for anti-HCV by enzyme-linked immunosorbent assay (ELISA). Confirmatory testing was done using a second-generation RIBA. Hepatitis C viral RNA was detected in serum using the polymerase chain reaction. Liver biopsies were obtained from the organ donor and interpreted blindly by a pathologist unaware of the clinical data. Liver chemistry profiles and serum sample analysis for HCV RNA were done for transplant recipients.

Results: From the 484 cadaver organ donors, 89 samples $(18 \% ; 95 \%$ CI, $15 \%$ to $21 \%)$ were reactive by ELISA. Of these, $33(6.8 \%$; CI, $4.6 \%$ to $9 \%)$ were RIBA seropositive. Hepatitis $C$ viral RNA sequences were detected in $50 \%$ of the RIBA-positive serum samples tested. Liver tissue was available from 24 of the 33 RIBA-positive donors and showed chronic active hepatitis in 16, chronic persistent hepatitis in 2 , and no abnormality in 6 . Among the 46 recipients of a kidney from a RIBA-positive donor, $13(28 \%$; CI, $15 \%$ to $41 \%)$ developed post-transplant liver disease, of which only 4 cases were highly suggestive of viral transmission from the donor. Little morbidity and no mortality could be attributed to liver disease in this cohort of recipients.

Conclusions: These data suggest that HCV transmission by organ transplantation is low and that the consequences of infection are small. If the medical condition of the potential recipient is so serious that other options no longer exist, the use of an organ from an anti-HCV-seropositive donor should be considered.

\section{COMMENTS}

When one considers HCV infection and organ transplantation, two questions call for answers: first, what is the actual transmission rate of hepatitis $\mathrm{C}$ virus (HCV) during transplantation, and second, what are the consequences of acquisition of HCV for the graft recipient? 
Previous studies of HCV transmission have been hampered by the lack of sensitivity and specificity of antibody tests for HCV infection (1). Lack of predictive value of antibody tests for HCV will result in the destruction of many organs that might have been safely used for transplantation. Additionally, use of an HCV-infected organ may be indicated if the clinical course of $\mathrm{HCV}$ infection acquired through transplantation is relatively benign. There is little doubt that a severe shortage of all types of organs for transplantation exists, a shortage with real clinical consequences. For example, from 1988 to 1992 the number of patients awaiting organ transplantation rose from 13,000 to 24,000 , and the number of patients per annum who died while waiting for an organ rose from 1,500 to 2,500 (2).

These two studies, by Pereira et al. and Roth et al., used detection of HCV RNA by polymerase chain reaction $(\mathrm{PCR})$ to definitively determine the presence of hepatitis $\mathrm{C}$ infection. Each study began with the identification of a group of organ donors that were HCV antibody (anti-HCV)-positive on first-generation ELISA. Further studies were made in this group of organ donors only. This design created a problem: transmission of HCV by donors positive for HCV RNA but negative for anti-HCV was not studied. This mode of transmission may account for a significant percentage of HCV infection after transplantation because HCV viremia without detectable anti-HCV is well described. Determination of the frequency of transmission of HCV from anti-HCV-negative donors awaits prospective study.

Anti-HCV positivity among the donors in these two studies was quite different. Pereira et al. found that 13 (2\%) of 716 donors were anti-HCV positive. Of 11 anti-HCV-positive donors studied, $9(82 \%)$ were HCV RNA positive. In Roth's study 89 (18\%) of 484 donors were anti-HCV-positive; of these, 33 were positive on second-generation recombinant immunoblot assay (RIBA) but only 15 were HCV RNA positive. The two groups of researchers apparently used the same arbitrary cutoff for the first generation ELISA; Pereira had only about two false-positive donors (18\%) and Roth had roughly 74 false-positive donors (83\%). Although major differences among antibody assays were noted in the evaluation of the donor groups, the final PCR analysis gave similar results; $2 \%$ and $3 \%$ of the donors were $\mathrm{HCV}$ RNA positive in Pereira's group and in Roth's group, respectively. These differences illustrate the need for highly sensitive yet specific tests for HCV in screening organ donors to prevent the inadvertent transmission of $\mathrm{HCV}$ and the wastage of organs from donors who are not infected with the virus. This technology is being developed and may soon be available in the form of the clinical application of PCR or a chemoluminescent branched-chain DNA hybridization assay for the detection of HCV RNA (being developed by Chiron Corp., Emeryville, CA).

To evaluate the effect on the recipient of an organ from an anti-HCV-positive donor, Pereira et al. used PCR to identify HCV RNA in serum of recipients before and after transplantation. All HCV RNA-negative recipients of organs from HCV RNA-positive donors became positive for HCV RNA. Of the recipients in whom serum HCV RNA was detected after transplantation, anti-HCV was found in 35\% to $70 \%$ of cases, depending on the test used. No HCV RNA-negative recipient who received a HCV RNA-negative organ became infected, although such patients were few. The type of organ transplanted (heart, liver or kidney) did not appear to have an influence on the transmission of HCV from an infected donor to a recipient but, again, the numbers were small.

In contrast, Roth et al. have PCR data on donor sera only; they do not have PCR confirmation of HCV infection in organ recipients. The absence of this "gold standard" confounds interpretation of positive or negative antibody tests. For example, they found that 13 of 15 anti-HCV (by RIBA)-negative recipients who received an anti-HCV (by RIBA)-positive organ remained RIBA negative after $1 \mathrm{yr}$. These data led Roth et al. to conclude that HCV transmission by organ transplantation is low and that the consequences of infection are small. However, 9 of the 15 recipients received organs from HCV RNA-negative donors. Among the six recipients who received organs from HCV RNA-positive donors, only one was RIBA positive during the follow-up period. But four of these six recipients had contracted chronic hepatitis after $1 \mathrm{yr}$. The serum HCV RNA data from Pereira et al. would suggest that all of these recipients with hepatitis in Roth's study were infected with HCV. Data published in abstract by Wreghitt et al. (3) support this conclusion. In their study, 14 patients-who were all anti-HCV-negative before transplantation - received organs from donors who were anti-HCV-positive on second-generation RIBA. Thirteen of these recipients became infected with HCV, including eight who remained anti-HCV negative but were HCV RNA positive on PCR. It should be mentioned that detection of serum HCV RNA is not a foolproof measure of HCV infection. Wright et al. (4) found two liver transplant recipients without detectable HCV RNA in serum who had hepatic HCV RNA.

More difficult to determine are the long-term clinical consequences for patients who receive HCV-infected organs. It is probable that at least $50 \%$ of persons who acquire HCV will progress to chronic liver disease, and HCV infection may have a significantly different clinical course in immunosuppressed transplant patients (5). The studies under commentary here do not have sufficient lengths of follow-up to answer these questions. Nevertheless, the data of Pereira et al. (6), along with those of Wright et al. (4) and Poterucha et al. (7) suggest that it is premature to dismiss $\mathrm{HCV}$ infection transmitted through transplantation or transplantationrelated blood transfusion as having little clinical importance. Thus the current recommendation of the UNOS Ad Hoc Donations Committee to eschew kidney grafts from donors with active viral hepatitis seems prudent (2).

Liver transplant recipients are at greater risk of $\mathrm{HCV}$ 
transmission at the time of transplantation because of the many units of blood products required at the time of surgery. Wright et al. (4) reports that 8 of 17 patients who acquired HCV did so after the blood bank began screening samples with a first-generation ELISA. The average liver recipient received 69 units of blood. Wright and others (8-10) have also shown that nearly all liver recipients who were infected with HCV before transplantation reinfected their grafts after transplantation. The issue of whether HCV-infected organs can be given to anti-HCV-positive recipients is probably more important in liver transplant patients. The safety of this practice is unknown, but Pereira et al. outline several reasons why it may not be safe. Anti-HCV is not protective against reinfection with $\mathrm{HCV}$, and the consequences of reinfection with different strains of $\mathrm{HCV}$ are unknown. Farci et al. (11) recently demonstrated in chimpanzees the lack of protection by HCV antibodies against reinfection with the same strain and different strains of HCV. But they did observe that in those chimpanzees that were viremic in addition to having HCV antibodies, attempts to reinfect them with a second strain were not successful. Thus the question of transplanting an infected organ into a HCV-viremic individual may be open to further study.

We draw the following conclusions from our review of these recent studies: first, it appears that most recipients of organs from HCV-infected donors will become infected by HCV. Second, detection of HCV RNA by PCR should offer a marked improvement over antibody tests in identifying donors who are infected. (This conjecture was not tested in the studies under commentary.) Third, the clinical courses of patients who receive HCV-infected organ should be studied further. It seems unduly optimistic to consider these infections trivial. Finally, the decision to transplant an $\mathrm{HCV}$-infected organ into a patient with end-stage organ disease remains a complex issue in which possible benefit must be weighed against possible harm. The studies under review here emphasize the need for measurement of HCV viremia, rather than anti-HCV antibodies, as the best method to document active HCV infection in potential organ donors and recipients.

W. Michael MCDONNELL, M.D. MICHAEL R. LUCEY, M.D., F.R.C.P.I. Department of Internal Medicine University of Michigan Medical School Ann Arbor, Michigan 48109-0362

\section{REFERENCES}

1. Estaban JI, Lopez-Talavera JC, Genesca J, et al. High rate of infectivity and liver disease in blood donors with antibodies to hepatitis C virus. Ann Intern Med 1991;115:443-449.

2. Alexander JW. Expanded donor criteria: background and suggestions for kidney donation. Transplant Proc, in press.

3. Wreghitt TG, Gray JJ, Allain JP, et al. Frequent transmission of HCV by organ donation [Abstract]. HePATOLOGY 1992;16:47A.

4. Wright TL, Donegan E, Hsu HH, et al. Recurrent and acquired
HCV infection in liver transplant recipients. Gastroenterology 1992;103:317-322.

5. Chizoulleres O, Kim M, Ferrell L, et al. Quantitative study of hepatitis $\mathrm{C}$ virus in liver transplant recipients [Abstract]. HEPATOLOGY 1992;16:45A.

6. Pereira BJG, Milford EL, Kirkman RL, Levey AS. Transmission of hepatitis $\mathrm{C}$ virus by organ transplantation. N Engl J Med 1991;325:454-460.

7. Poterucha JJ, Rakela J, Lumeng L, Lee CH, Taswell F, Weisner $\mathrm{RH}$. Diagnosis of chronic hepatitis $\mathrm{C}$ after liver transplantation by the detection of viral sequences with polymerase chain reaction. HEPATOLOGY 1992;15:42-45.

8. Gretch DR, dela Rosa C, Perkins J, Corey L, Carithers RL. HCV infection in liver transplant recipients: chronic reinfection universal, de novo acquisition rare [Abstract]. HEPATOLOGY 1992; 16:45A.

9. Feray C, Gigou M, Samuel D, et al. Natural history of HCV infection after liver transplantation [Abstract]. HEPATOLOGY 1992; $16: 47 \mathrm{~A}$.

10. Sallie R, Cohen A, Rayner A, et al. Hepatitis C recurrence following orthotopic liver transplantation: a PCR and histological study [Abstract]. HEPATOLOGY 1992;16:48A.

11. Farci $\mathrm{P}$, Alter HJ, Govindarajan $\mathrm{S}$, et al. Lack of protective immunity against reinfection with hepatitis $\mathrm{C}$ virus. Science 1992;258:135-140.

\section{TRANSFORMING GROWTH FACTOR- $\beta 1$ : THERE IS REGULATION BEYOND TRANSCRIPTION}

Kim S-J, Park P, Koeller D, Kim KY, Wakefield LM, Sporn $M B$, Roberts $A B$. Post-transcriptional regulation of the human transforming growth factor- $\beta 1$ gene. J Biol Chem 1992;267:13702-13707.

\section{ABSTRACT}

Since many lines of evidence suggest that expression of the transforming growth factor- $\beta 1$ (TGF- $\beta 1$ ) gene may be regulated post-transcriptionally, we examined the effect of the $5^{\prime}$-untranslated region (UTR) of this gene on TGF- $\beta 1$ expression. For this purpose, fragments of the 840-nucleotide highly GC-rich TGF- $\beta 1$ $5^{\prime}$-UTR were inserted into the $5^{\prime}$-UTR of the structural gene for human growth hormone driven by the simian virus 40 early promoter. A portion of the 5 '-UTR of TGF- $\beta 1$ mRNA spanning the sequences from +11 to +147 was shown to inhibit growth hormone expression by as much as 22-fold. This effect was cell-specific; growth hormone production was inhibited in PC-3 human prostate adenocarcinoma and A-549 human lung adenocarcinoma cells, while no effect was seen in rat pheochromocytoma PC12 cells, which show efficient translation of endogenous TGF- $\beta 1$ mRNA. Computer analysis showed that this region of the $5^{\prime}$-UTR contained a stable secondary stem-loop structure spanning sequences +49 to +76 . This stem-loop region alone is sufficient to inhibit expression of the growth hormone gene, suggesting that it plays an important role in post-transcriptional regulation of TGF- $\beta 1$ gene expression.

\section{COMMENTS}

The transforming growth factor (TGF)- $\beta$ s are a family of multifunctional peptides that regulate cell proliferation, function and differentiation. Hepatologists are particularly interested in TGF- $\beta_{1}$ because of its role in 